\title{
Heterogeneity type of coarse peridotite xenoliths from Udachnaya kimberlite pipe (Yakutia) and their origens
}

\author{
Malygina E.V., Pokhilenko N.P. \\ Institute of Geology and Mineralogy,SB RAS, Novosibirsk, Russia
}

\begin{abstract}
Introduction
Numerous solid phase and metasomatic transformations, which point to vertical heterogeneity of the mantle matter, were found in the xenoliths of mantle rocks from the kimberlites of Yakutia (Sobolev et al., 1984, Pokhilenko et al., 1999; Solov'eva et al., 1994.; Solov'eva, 2007; Boyd et al., 1997; Shimizu et al., 1997). Heterogeneity of mineral paragenesis is a result of metasomatic transformations of the mantle substance or change of thermodynamic parameters as lithosphere mantle of ancient platforms becomes active. Experimental modeling of phase relations in the conditions of garnet-peridotite facies demonstrates an essential effect of high pressures on chemical and phase reactions (Litvin et al., 2006). Compositional variations of the same rock-forming minerals within the concrete xenolith are an evidence of the evolution of the upper mantle substance and are conditioned by the peculiarities of garnetization of spinel peridotites in the lithosphere mantle in the central part of the Siberian platform.
\end{abstract}

Complex of coarse peridotite xenoliths from the Udachnaya kimberlite pipe (central part of the Siberian platform) is represented by paragenesis varying in chemical composition and P-T parameters of formation (Malygina et al., 2003). Coarse peridotite xenoliths are distingushed as rocks with equilibrium and unequilibrium mineral associations. Chemical unequilibrium of the main rock forming mineral grains from 53 large samples was analysed. Studied rocks by textural peculiarities and bulk chemistry are similar to equilibrium granular peridotites. Mineral chemistry has been studied using Camebax-micro electron probe and Jeol Super Probe 7800.

The most widespread main types of heterogeneities are variations of the chemical compositions of the rockforming mineral grains of the same name (garnets, orthopyroxenes and Cr-spinellides), situated in differend parts of xenolith. These minerals are homogeneous within the grains on composition of the main oxides $\left(\mathrm{Cr}_{2} \mathrm{O}_{3}, \mathrm{MgO}, \mathrm{CaO}, \mathrm{FeO}\right)$. The variations in composition were recognazed between spinels and enstatites, which form symplektite intergrowth structures, and their discrete grains. The zoning of the large garnet grains from the most deep-seated garnet peridotites was found.

\section{Mineral composition}

Garnets are presented by $\mathrm{Cr}$-pyropes $\left(\mathrm{Cr}_{2} \mathrm{O}_{3}\right.$ up to 11,8 wt.\%). Garnets with variable chemical compositions were revealed in a number of xenoliths. $\mathrm{Cr}_{2} \mathrm{O}_{3}$ content usually varies by $2-3$ wt. $\%\left(\mathrm{Cr}_{2} \mathrm{O}_{3}\right.$ content in particular xenoliths is 4,12-6,68 and 6,21-9,19 wt.\%), in some cases $\mathrm{Cr}_{2} \mathrm{O}_{3}$ content varies up to 6 wt.\% $(3,47-9,39$ wt.\%). Similar variations cause the change of garnet component composition: uvarovite, knorringite and grossular. The presence of garnet grains of significantly different chemical composition (Crenriched subcalcic pyrope of harzburgite-dunite paragenesis and garnet of typical lherzolite composition) is the most important phenomenon. Character of the change of $\mathrm{Cr}$ and $\mathrm{Ca}$ ratio in different grains shows that harzburgite-dunite paragenesis changes to lherzolite one.

Same samples contain zonal garnet grains Microprobe profile cross the grain revealed concentric zonality in major oxides distribution. Homogenous nucleus has maximal $\mathrm{Cr}_{2} \mathrm{O}_{3}(8,09$ wt.\%) and $\mathrm{CaO}(7,19$ wt.\%), decreased $\mathrm{MgO}\left(18,1\right.$ wt.\%) and $\mathrm{Na}_{2} \mathrm{O}(0,03$ wt.\%), $\mathrm{TiO}_{2}$ is entirely absent. Peripheral zones are depleted in $\mathrm{Cr}_{2} \mathrm{O}_{3}$ (6,68 wt.\%), $\mathrm{CaO}$ (5,06 wt.\%) and enriched in $\mathrm{MgO}$ (20,0 wt.\%), $\mathrm{Na}_{2} \mathrm{O}\left(0,07\right.$ wt.\%) and $\mathrm{TiO}_{2}(0,58$ wt.\%).

Cr-spinellides form continuous series from essentially alumina varieties $\left(49,9\right.$ wt. $\% \mathrm{Al}_{2} \mathrm{O}_{3}$ and 18,5 wt. $\%$ $\left.\mathrm{Cr}_{2} \mathrm{O}_{3}\right)$ to chromites $\left(6,3\right.$ wt. $\% \mathrm{Al}_{2} \mathrm{O}_{3}$ and 64,6 wt. $\%$ $\mathrm{Cr}_{2} \mathrm{O}_{3}$ ). Compositional variations in discrete grains appear mainly in $\mathrm{Cr}_{2} \mathrm{O}_{3}-\mathrm{Al}_{2} \mathrm{O}_{3}$ contents. $\mathrm{Cr}_{2} \mathrm{O}_{3}$ content in different chromespinelide grains usually varies within the range up to 2 wt.\%. Maximal noted differences reach $10-11$ wt.\% $\left(\mathrm{Cr}_{2} \mathrm{O}_{3}\right.$ content varies from 26,5 to 37,6 wt. $\%$ or 31,6 to 42 wt.\%, respectively). $\mathrm{FeO}$ content sharply increases in some cases as $\mathrm{Cr}_{2} \mathrm{O}_{3}$ content decreases and $\mathrm{Al}_{2} \mathrm{O}_{3}$ increases. This increases the coefficient of $\mathrm{Fe}$ oxidation and suggests that magnetite component takes greater significance. 
$\mathrm{Cr}_{2} \mathrm{O}_{3}$ content variations in different chromespinellide grains are often followed by changes in $\mathrm{TiO}_{2}$ content. Variations in Ti values are 0,5-0,7 wt.\%. Fe/( $\mathrm{Mg}+\mathrm{Fe})$ ratio in chromespinellides alters on average $1,5-2 \%$ for specific xenoliths and reach $4 \%$ in some samples.

Variation of compositions of orthopyroxene grains within one xenolith appear in change of chrome, aluminium, calcium and iron contents. $\mathrm{Al}_{2} \mathrm{O}_{3}$ content vary usually inside interval 1,5-4 wt. $\%$ in different enstatite grains (e.g. from 0,26 to 4,08 wt.\%). In this case the range of $\mathrm{Cr}_{2} \mathrm{O}_{3}$ values is from 0,2 to $0,9 \mathrm{wt} . \%$, $\mathrm{CaO}-0,5-1,3$ wt. $\%$. $\mathrm{Ca} /(\mathrm{Ca}+\mathrm{Mg})$ ratios vary on average 1,5-2 times, rarely 3-4 times. Orthopyroxenes from simplectite-like decay structures with chromespinellides are often characterized by decreased $\mathrm{Cr}_{2} \mathrm{O}_{3}$ content as compared with enstatite discrete grains from the bulk mass, where a spread of $\mathrm{Cr}_{2} \mathrm{O}_{3}$ content is also observed. Negative correlation is evident between $\mathrm{Al}_{2} \mathrm{O}_{3}$ and $\mathrm{CaO}$ contents on the one hand and $\mathrm{Cr}_{2} \mathrm{O}_{3}$ content on the other. $\mathrm{Cr}_{2} \mathrm{O}_{3}$ content of orthopyroxene from orthopyroxene-garnet growths can be higher, lower or similar to that of enstatites from the bulk olivine.

Composition variations of clinopyroxene grains does not vary significantly and observe lot rarely. They relates mainly to the changes of $\mathrm{Cr}_{2} \mathrm{O}_{3}$ and $\mathrm{Al}_{2} \mathrm{O}_{3}$ contents variations.

Chemical homogeneity in the majority of the samples was observed only in one of the minerals. Inhomogeneous mineral pairs - garnet-orthopyroxene and spinel-orthopyroxene growths - are rarely found. Probably the reasons, which are responsible for the change of garnet or spinellide composition, cause regular change of chemistry of associating pyroxenes. The only display of compositions inhomogeneity of three above mentioned minerals in one xenolith has been noted.

\section{Petrology}

Significant compositional variations of xenolith rockforming minerals in macro volume (xenolith volume) and micro volume (zonality of discrete grains, variations of minerals within growths) aren't associated with their transportation to the surface by kimberlite magma. They testify that PT-parameters of equlibrium or local variation of composition were changed because of metasomating fluid-melts were penetrated including time near to the process of kimberlite melts generation.

In spite of the grains of one and the same mineral differing in chemical composition are found in various parts of xenolith it is possible to believe that the condition of chemical equilibrium between neighboring grains in separate small areas of the rock has been reached. It was stable over prolonged period due to the low diffusion rates of exchange reactions under Comparatively low temperatures of equilibrium which are typical for the most of studied sumples.

The estimations of P-T parameters for garnet-spinel and spinel peridotites comprising unequilibrium mineral associations show that equilibrium has upseted in rock a few times. A combined temperature interval for the grained peridotites with the coexisting garnet and chrome-spinellide is $750-1120^{\circ} \mathrm{C}$ and pressure interval is 20-50 kbar. (MacGregor, 1984; BreyKohler, 1990). Scattering of temperature values for mineral pairs from the one xenolith is on average 50$150^{\circ} \mathrm{C}$ and dispersal of pressure values reaches $10-$ 15 kbar.

It is suppotred that the value of P-T conditions, which correspond to the lower temperature paragenesis from every unequilibrium xenolith, characterize initial P-T parametes of mantle rocks similar to that of equilibrium xenoliths. Values, which correspond to the higher temperature paragenesis, relate to the most heated parts of the rock and reflect the state of activated mantle associated with penetration of deepseated fluid-melts and subsequent dynamic processes, which probably come before the process of kimberlite formation.

\section{Discussion}

The occurence of mineral grain with different chemical compositions in one xenolith can be illustrated by the development of the reaction of garnetization. The beginning and the end of the reaction apart from $\mathrm{P}-\mathrm{T}$ conditions are controlled by the value of $\mathrm{Cr} /(\mathrm{Cr}+\mathrm{Al})$, wich connected with the degree of depletion of mantle matter:

$$
\begin{gathered}
\underset{\text { enstatite }}{4 \mathrm{MgSiO}_{3}}+\underset{\text { spinel }}{\mathrm{Mg}(\mathrm{Al}, \mathrm{Cr})_{2} \mathrm{O}_{4}} \rightarrow \\
\rightarrow \underset{\text { pyrope }}{\mathrm{Mg}_{3}(\mathrm{Al}, \mathrm{Cr})_{2} \mathrm{Si}_{3} \mathrm{O}_{12}}+\underset{\text { olivine }}{\mathrm{Mg}_{2} \mathrm{SiO}_{4}}
\end{gathered}
$$

Reaction changes occur in grains of the rock-forming minerals if they are situated directly alongside each other. Composition of minerals does not changes if garnet, spinel or orthopyroxene grains are completely divided in olivine matrix. Reaction of garnetization pass with significant changing of chemical composition of the minerals and it has direct or reverse spread because of the location of xenolith in the mantle section and the character of alteration of P-T parameters. Thus, the same minerals with different mineral composition can be observed in one xenolith.

Most probably studied xenoliths occurred at the boundary of mantle blocks subjected to sub vertical movements and it results in additional heating before further transportation to the surface by kimberlite magma. Garnet zonality is defined mainly by the interaction between depleted mantle rocks and fluid, which favours introduction of substance from the 
deeper mantle horizons (Sobolev et al., 1984; Solov'eva et al., 1994; Pokhilenko et al., 1999).

Two models can be used to explain the presence of mineral grains of significantly different composition in one xenolith. First of all, by the model of two-stage formation of polymict peridotites by which migration of mantle fluid from the deepest horizons to the most higher mantle levels has assisted partial transportation of xenoliths. Metasomatic reorganization of mineral phases and rock consolidation occurred in a new thermodynamic conditions (Lawless et al., 1979). Second, by the process of mixing of heterogeneous deep-seated substance during inside-mantle diapirizm and specific high-temperature mantle metasomatism approaching to the processes of partial melting in their parameters (Lazko, Serenko, 1986).

\section{References}

Boyd, S.R., Pokhilenko, N.P., Pearson, S.A. et al, 1997. Composition of the Siberian craton mantle: evidence from Udachnaya peridotite xenoliths. Contrib. Mineral. Petrol., 128, 228-246.

Brey, G.P., Kohler, T., 1990. Geothermobaromerty in fourphase lherzolites II. New thermobarometers, and practical assessment of existing thermobarometers . J. of Petrology, 31, 6, 1353-1378.

Lazko, E.E., Serenko, V.P., 1986. Unequllibrium mineral assocoations in the most deep xenoliths from kimberlits and their origens. Origen and evolution of magmatic formations in the Earth history: Abstr. Of 7th All-Union petrografy conference. Novosibirsk, 71-72. (in Russian)

Litvin, Yu.A., Litvin, V.Yu., Kadik, A.A., Zharikov, V.A., 2006. Formation of reactionary garnets under melting of the carbonatite system $\mathrm{MgCO}_{3}-\mathrm{CaCO}_{3}-\mathrm{NaAlSiO}_{4}$ $\mathrm{SiO}_{2}(\mathrm{P}=7.0 \mathrm{GPa})$. Report RAS, 406, 1, 83-89.

Lawless, P.J., Garney, J.J., Dawson, J.B., 1979. Polymict peridotites from Bultfontein and De Beers Mine, Kimberly, South Africa. Mantle Sample: Inclusions in Kimberlites and Other Volcanics: Proceedings of the 2nd Int. Kimberlite Conf. Washington, D.C., 2, 145155.

MacGregor, I.D., 1974. The system $\mathrm{MgO}-\mathrm{Al}_{2} \mathrm{O}_{3}-\mathrm{SiO}_{2}$ : solubility of $\mathrm{Al}_{2} \mathrm{O}_{3}$ in enstatite for spinel and garnet peridotite compositions. Amer. Mineral, 59, 1-2, 110119.

Malygina, E., Pokhilenko, N., Sobolev, N., 2003. Coarse peridotite xenoliths of Udachnaya kimberlite pipe, Yakutia: garnetization of peridotites of the Central Siberian platform lithospheric mantle. 8th International Kimberlite conference, Victoria, BC, Canada, June 22-27th: Extended Abstracts, FLA_0191, CD-ROM.

Pokhilenko, N.P., Sobolev, N.V., Kuligin, S.S., Shimizu, N., 1999. Peculiarities of distribution of pyroxenite paragenesis garnet in Yakutian kimberlites and some aspects of the evolution of the Siberian craton lithospheric mantle. VIIth Inter. Kimberlite Conf.: Proceedings, Cape Town, 2, 689-698.

Sobolev, N.V., Pokhilenko, N.P., Rodionov, A.S., 1984. Inhomogeneities of the deep-seated inclusions in kimberlites as an indication of the processes of dynamic evolution in the upper mantle substance. Abstr. of the 27th IGC, V, 10-11, 399-401.
Solov'eva, L.V., Vladimirov, B.M. et al., 1994. Kimberlites and kimberlite-like rocks: the Upper Mantle substance under ancient Platforms. Novosibirsk, Nauka, 256. (in Russian)

Solov'eva, L.V., 2007. Reworkiing of the mantle lithosphere of Iberian craton by reduced fluids in middle Paleozoic kimberlite event - geochemical consequences. Report RAS, 412, 6, 804-809.

Shimizu, N., Pokhilenko, N.P., Boyd, F.R. et al., 1997. Geochemical characteristicsnof mantle xenoliths from Udachnaya kimberlite pipe. Geol. Geophis., 38, 1, 194-205 (in Russian). 